\title{
Water Management Reporting in the Agro-Food Sector in South Africa
}

\author{
M. Isabel Sánchez-Hernández ${ }^{1, *}$ (i) , Rafael Robina-Ramírez ${ }^{2}$ and Willem De Clercq ${ }^{3}$ \\ 1 Research Visitor in Stellenbosch University, South Africa/Business Administration and Sociology \\ Department, School of Economics, University of Extremadura, Ave. Elvas s/n, 06006 Badajoz, Spain \\ 2 Research Visitor in Stellenbosch University, South Africa/Business Administration and Sociology \\ Department, School of Economics, University of Extremadura, 10071 Cáceres, Spain; rrobina@unex.es \\ 3 Researcher at the Water Institute, Stellenbosch University, Matieland 7602, South Africa; wpdc@sun.ac.za \\ * Correspondence: isanchez@unex.es; Tel.: +34-639-529-275
}

Received: 24 June 2017; Accepted: 27 October 2017; Published: 29 October 2017

\begin{abstract}
The purpose of the study is to assess whether Corporate Social Responsibility regarding water is considered relevant for sustainability in companies related to agriculture in South Africa, considering that their impact directly influences public access to water. To accomplish this purpose, a qualitative approach was developed through the study of the 22 existing companies from the agriculture sector, food and beverages, forest and paper production, and Tobacco, which published their last integrated report within the Global Reporting Initiative framework. A thematic content analysis was carried out, involving the analysis of the written sustainability reports. For data analyses, ATLAS.ti 7.1 software was used to match the main aspects related to water management. Pragmatic advice for practitioners derives from the research results, considering that Corporate Social Responsibility in general—and sustainable water management in particular-represents an opportunity for companies to get competitive advantages in the market. The study also determines the best practices in the field in South Africa with benchmarking purposes.
\end{abstract}

Keywords: water management; corporate social responsibility; sustainability; reporting; disclosure

\section{Introduction}

With the world's growing scarcity of natural resources such as water, it is imperative for governments to be cognizant of the scarcity factor, and distribute resources efficiently and adequately to residents [1-3]. According to the United Nations [4], water scarcity already affects every continent [5]. More than one billion people currently lack access to safe drinking water, and around 2.5 billion people lack access to improved sanitation. Water use has been growing at more than twice the rate of population increase in the last century and, although there is no global water scarcity as such, an increasing number of regions are chronically short of water.

In this context, South Africa has been classified as a water-scarce region [6]. Corporate Social Responsibility (CSR) should tend to become important for sustainable water management. In fact, companies have started recognizing that they can have a positive impact on preserving water resources and in granting people access to water [7]. The importance of disclosing both environmental and social information by big companies has gained attention and sustainability reporting is gaining prominence throughout the world [8] and also in South Africa [9]. Through this process, companies can communicate their current strategy specially referring to their sustainability practices. According to Lambooy [10], the moral responsibility increases in weak governance zones or where the water supply is limited.

Although sustainability disclosure has been the subject of substantial academic research for more than four decades, the disclosure literature is dominated by studies in the industrialized countries 
of Western Europe and the USA [11-13], although responsibility reporting is being undertaken increasingly in emerging and developing countries as well [14-16]. It has been recognized that it is not possible to generalize the results of developed countries to less developed countries as the stage of economic development is likely to be an important factor affecting sustainable practices [17]. Moreover, some works about CSR in developing countries such as Idemudia's contribution [18], have put emphasis on contextual factors. Consequently, cultural and national differences are likely to affect sustainable practices in general and reporting practices in particular $[19,20]$. Though some improvements have been made—as will be shown later-there is still relative paucity of studies on sustainability reporting in South Africa.

This study addresses the above-mentioned imbalance through an examination of sustainability disclosures by South African companies to fill the gap with new knowledge. The water-food nexus is central to the sustainability of South Africa's future because, unless both elements are in balance, communities will not be able to grow up assuring the future of next generations. The purpose of the study is to assess whether CSR aspects regarding water are considered relevant for sustainability in companies related to agriculture in South Africa. This research proposition is particularly relevant in agriculture companies but also in related companies, the agro-food sector, considering that their impact directly influences public access to water.

To accomplish this purpose, the following sections are devoted to contextualize the study and to review the academic literature in the field. Later, we will follow a qualitative approach, through the study of selection of twenty-two sustainability reports and complementary material from companies in agriculture and related sectors in South Africa. Finally, results are presented and discussed determining the best practices in the field and practical recommendations.

\section{Theoretical Background}

The urgency of global environmental and social threats is increasing around the world [21]. Because of that, the integration of sustainability into core business systems and decision-making, and capturing the competitive advantage this offers, becomes more critical than ever [22]. However, despite some attempts at mandating disclosure in some countries, such as Spain [23] and France [24] (Delbard, 2008), disclosure remains less normative than expected because of the lack of compliance, and focus on business legitimacy to operate [25].

Legitimacy theory offers a powerful mechanism for understanding voluntary social and environmental disclosures made by organizations. Without invalidating the likelihood that other social theories have explanatory power to the increase of sustainability disclosures since the early 1980s, some authors have defended that legitimacy theory as one of the best explanations in different context such as in Australia [26], Germany [27] and France [25].

Legitimacy theory has its roots in the existing social contract between companies and society. Suchman [28] (p. 574), defined legitimacy as "a generalized perception or assumption that the actions of any entity are desirable, proper, or appropriate within some socially constructed system of norms, values, beliefs, and definitions". According to Magness [29], the legitimacy theory begins with the assumption that an organization has no inherent right to exist, and this right has to be conferred upon by the society in which it operates. However, to get this right, the company's value system and its actions have to be perceived to be congruent with that of the society. Consequently, social and environmental disclosure has the aim to influence and to change external parties' views of the organization. To publish what the company does, and how it is managing its resources, is expected to have positive impact on stakeholders reinforcing legitimacy to operate, especially in a context such as South Africa where Integrated Report is compulsory for listed companies into the Johannesburg Stock Exchange List, the JSE listing [30].

To summarize, and according to Suchman [28], the Legitimacy theory has the relevant role of explaining the behavior of organizations in implementing and developing voluntary environmental and social disclosure of information in order to fulfill their contract with society. This enables the 
recognition and acceptance of their objectives and the survival in an agitated and unstable habitat. That should be the main reason for voluntary disclosure of social and environmental information for companies in controversial sectors such as the tobacco industry.

Related to companies' disclosure task, first there was financial reporting, later came sustainability reporting, and now it is the turn of integrated reporting. The Integrated Reporting Committee (IRC) of South Africa (2017) describes integrated reporting as a set to become the way companies around the world report their performance. In February 2010, the principles of the King Code of Governance of 2009 (King III), including those that recommended the integrated report, were incorporated into the JSE's listings requirements and listed companies were obliged to apply the King III principles or publicly explain their reasons for deviating from them (applying to financial years starting on and after 1 March 2010). The aim of the integrated report is to tell the story of the company, its strategy, who it is and what it does and how it creates value, opportunities and risks, its business model and governance, and the performance against its strategic objectives in a way that gives stakeholders a holistic view of the company and its future. All that information is written in a clear and concise published document, accessible to any stakeholder.

The ethical background of King III is rooted in the South African Constitution that fosters sustainability by imposing responsibilities upon individuals and juristic persons, including business organizations, for the realization of fundamental rights. According to De Villiers et al. [31], this means that business organizations should be responsible citizens and they could be held accountable.

Moving from the Legitimacy theory, related to the moral license to operate, the business case for reporting has also taken the attention of companies. According to Perrini [32], financial, sustainability, or integrated reports are the tools companies use to delineate their position on CSR and to guide them in developing good business practices. There are so many reasons for reporting such as improving competitiveness and market positioning, risk profile and risk management [22,33], improving investor relations and access to capital [34], firm performance [35] and, in general, improving company reputation [36].

Complementing the Legitimacy Theory, the Stakeholders Theory [37-39] strongly explains the increase of disclosure of environmental and social information by organizations. According to this theory, an organization must meet its responsibilities towards shareholders. Nowadays, the business and the academic world have embraced the stakeholders' logic. That means that it is expected that organizations behave ethically and engage also in reporting activities as a form of business response to new demands in society.

According to Handy [40], the purpose of a business is not only to make a profit but also to make a profit by doing something more or better than its competitors. This "something" should be a moral or ethical issue that will be the real justification for the business [41]. To be responsible implies that any organization has responsibilities beyond profit-seeking and must conduct entrepreneurial actions in a manner that also meets social and environmental standards.

\section{Context of Analysis}

\subsection{Water Scarcity in South Africa}

South Africa is located in a semi-arid region and considered among one of the 30 driest countries in the world [42]. De Wet [43] has highlighted South Africa could face a situation of extensive water scarcity unless current reserves and usage patterns are managed properly. That is why water is said to be a national asset, on which the economic and social development of a country such as South Africa depends [44]. In its twenty-year review of the state of water in South Africa, the Presidency reported that "South Africa is a water-scarce country, with very limited availability of raw water ..." This has subsequently led to stress on economic growth. The year 2015/2016 brought the worst drought experienced by South Africa since 1992, which has put a lot of strain on the country's already diminished water resources [3]. 
Water scarcity is both a natural and a human-made phenomenon. There is enough freshwater for the world's population but it is distributed unevenly and too much of it is wasted, polluted and unsustainably managed [45]. Only a small proportion of wastewater is collected, and an even smaller fraction is treated [46]. Nowadays, South Africa is facing unprecedented challenges in meeting the rising demand for potable water [47]. Population and water demand are growing very rapidly in some cities. The population in 17 of the 31 cities is growing at an annual rate of more than $3.7 \%$. This exacerbates the challenges of water management and highlights the need to explore diverse water sources, including reused wastewater, to ensure that water is fit for purpose and to exploit innovative technologies [48].

Therefore, ensuring safe water supply for South Africa and the rest of the world is possible, but everyone has to accept responsibility in this regard at every level of society, from elected politicians to individual households. It is also assumed that companies bear a legal and a moral responsibility for the environmental consequences of their water management [10]. Consequently, companies can help to solve the current problems associated with the increasing pollution of groundwater and surface water and contaminated water supplies, and at the same time address environmental problems and concerns about economic development and growth [49].

\subsection{Water Management and the Agro-Food Sector}

Around the world, and especially in South Africa, water management is fundamentally a question of environmental and social justice. The ethical dimension of water management could be split into three essential goals: equity, fairness and access between and across generations [50]. Debbané and Keil [51], arguing about sustainable water management and against neo-liberal political agendas, have identified different notions of environmental justice at all scales of the social realities tied to ethnicity, gender or class. Related to companies in South Africa, these authors have noticed, for instance, how wine industries used to take disproportionate amounts of water. Acknowledging the escalation of global water risks with an expansion of the water management expectation, CERES [22] has recently included a revised expectation about water into its roadmap for sustainability to address both, direct operational and supply chain impacts, within regions of high water risk.

According to Hill [52], sustainable companies do not exclude business development and profit. Sustainability rather guides companies along the journey of social responsibility and environmental protection. In fact, authors such as Fresner and Engelhardt [53] have defended cleaner production as an important starting point for the development of sustainable companies by improving the efficiency of the productive processes. In this respect, the organizational integration of sustainability through environmental teams has also been demonstrated to be useful $[54,55]$. In general, companies recognize how much more CSR improves firm performance [56,57]. For instance, in Africa, the case studies analyzed by Gumbo et al. [58] in Zimbabwe demonstrate that one challenge for developing countries is how to modernize the industrial processes by reducing water consumption and material usage and minimizing waste. In conclusion, cleaner production and water management are correlated concepts that combined, will result in both economical and ecological benefit.

In this context, the agro-food sector is one of the most important sectors of the economy of developing countries, encompassing agriculture, the food industry and retail [59]. The sector has the responsibility of serving consumers with safe, readily available and affordable food. For that purpose, the agro-food sector needs to be efficient and to build on water control of processes.

This study analyzed the agriculture-related businesses because they have been traditionally high water users as well as sources of water pollution, and thus they used to be near the top of the environmental agenda in every nation in which they operate [8]. Agro-food, as an economic sector, is the fourth most important water user in South Africa and sustainable production in this sector necessarily involves water concerns. 


\subsection{CSR and Reporting in South Africa}

The Fifka' meta-analysis [16] about CSR reporting in developed and developing countries demonstrated that the number of studies in Africa was very limited although most of them came from South Africa.

From the University of Pretoria, De Villiers and co-authors have done some important contributions. De Villiers [60] analyzed the reasons for the disclosure of environmental information in annual reports and in separate environmental reports in South Africa. He found that companies responded primarily to stakeholders' pressure, primarily investors in listed companies but also customers and government. Later, De Villiers and Barnard [61], when comparing mining companies with other large companies, corroborated the legitimacy theory. Mining companies had very good disclosure because of their need to legitimize their operations avoiding conflicts with society assuming their clear environmental impact and showing the ways to minimize it. De Villiers [62] found that South African managers were positive about reporting in general and towards reporting on a compulsory basis in particular, making this evidence a strong case for the introduction of legislation to regulate reporting issues.

In line with previous works, De Villiers and Van Staden [63] have explained why the King reports have emphasized social and environmental governance to a greater extent than similar guidelines in other countries. The reason of this social setting is due to the recent historical process, between 1990 and 1994, to establish a new and fair political order following apartheid. Coming back to the legitimacy theory, the King codes of governance principles in South Africa-focusing attention on social and environmental issues-have contributed to legitimate sustainable companies to operate and make a profit. De Villiers et al. [31] have provided new research in the area of integrated reporting focused on South Africa at a country level for being pioneer in adopting the new trend of increasing the account for non-financial performance.

In addition to this reviewed research focused on the perceptions and attitudes toward disclosure in South Africa, other researchers such as Dawkins and Ngunjiri [64] from USA have contributed to the existing knowledge about reporting in South Africa by comparing it with that of the Global Fortune list, the annual ranking of the world's largest corporations.

Mitchell and Hill [65] have determined the feasibility of and challenges to the implementation of the Global Reporting Initiative (GRI) in industry in South Africa. Their findings showed that many of the susceptible areas to be disclosed by the GRI could be partially reported upon by many companies in most sectors, based on current reporting systems. In line with Gray and Bebbington [66], the authors recommended ISO 14001 certification for ensuring environmental protection, rather than simply integrated report disclosure.

Recently, the last KPMG study to "Corporate Responsibility Reporting" [67] points to South Africa, as one of the emerging economies that have the highest CSR reporting rates in the world, $99 \%$ to be exact. It is true that when legislation has been introduced by government, as it is the case, companies tend to respond and CSR reporting rates are seen to increase rapidly. In addition, and even considering that the uptake of integrated reporting is still slow on average in the world (11\% in 2015), in South Africa, the rate continues to be the highest (91\% in 2015) because the practice is mandatory.

\section{Method and Procedure}

In the present study, we employed qualitative methodology ensuring the potential replication of the procedure by maintaining a predetermined coding agenda from previous relevant academic contributions, and detailed processes and documentation as described below.

\subsection{Sample and Data Collection}

We selected the companies' analyzed using purposeful sampling, which allowed us to identify disclosure-rich typical cases [68]. We followed the qualitative approach through the study of the twenty-two existing companies from the agriculture sector (two companies), food and beverages products 
(fifteen companies), forest and paper products (four companies), and Tobacco (one company), which published their last Integrated Report, within the GRI framework, considered at the moment an essential international reference for sustainability reporting as a proxy for organizational sustainability [69]. Table 1 shows the companies profile according to the information found in their reports.

The Integrated Report includes in just one document the information traditionally provided in the annual report, the sustainability report, and the corporate governance report. Other secondary data coming from their web pages and media have being also considered to improve the interpretation of the analytical results.

Table 1. Company Profiles.

\begin{tabular}{|c|c|}
\hline \multicolumn{2}{|r|}{ AGRICULTURE SECTOR } \\
\hline Crookers Brothers Group Limited & $\begin{array}{l}\text { Pioneer in the South African sugar industry and specialized in the production of primary } \\
\text { agricultural products, including sugar cane, bananas and deciduous fruit in South Africa, } \\
\text { Swaziland and Zambia, with a major new farming operation under development in } \\
\text { Mozambique for the production of macadamia nuts and annual crops. }\end{array}$ \\
\hline Senwes & $\begin{array}{l}\text { The Senwes Group is one of the leading agro-business companies in South Africa and has } \\
\text { an integrated business model to facilitate its core objective of making a meaningful } \\
\text { contribution to food security in South Africa in a sustainable manner. }\end{array}$ \\
\hline \multicolumn{2}{|r|}{ FOOD AND BEVERAGES PRODUCTS } \\
\hline AH-Vest Limited & $\begin{array}{l}\text { The company is engaged in offering a range of canned and bottled food products and is } \\
\text { also engaged in exporting its products. The Company's geographical segment includes } \\
\text { South Africa. The Company has its own distribution warehouse in the Kwa-Zulu Natal } \\
\text { province }(\mathrm{KZN}) \text {. }\end{array}$ \\
\hline Astral & A leading Southern African integrated poultry producer. \\
\hline Clover & $\begin{array}{l}\text { A leading and competitive branded consumer goods and products group operating in } \\
\text { South Africa and other selected African countries with core competencies in production, } \\
\text { distribution, sales and merchandising. }\end{array}$ \\
\hline Distell & $\begin{array}{l}\text { A key player in the alcohol beverages industry in South Africa, manufacturer and } \\
\text { marketer of wine, spirits and alcoholic beverages. }\end{array}$ \\
\hline Famous Brands & $\begin{array}{l}\text { A holding company under the category of consumer services: Travel and leisure and is } \\
\text { Africa's largest branded food service franchiser. }\end{array}$ \\
\hline KVW & One of the leading wine and spirits producers in South Africa. \\
\hline Nutritional Holdings Limited & $\begin{array}{l}\text { A manufacturer and distributor of fortified staple food products as well as a range of } \\
\text { medicines registered with the South African Medical Control Council and other } \\
\text { complimentary natural medicines. }\end{array}$ \\
\hline Oceana Group & $\begin{array}{l}\text { The largest fishing company in South Africa, and an important participant in the Namibian } \\
\text { fishing sector. }\end{array}$ \\
\hline Pionner & $\begin{array}{l}\text { A leading company in South Africa, producing and distributing a range of branded food } \\
\text { and beverage products. The Group operates mainly in South Africa, providing wholesale, } \\
\text { retail and informal trade customers with products of a consistently high standard. Pioneer } \\
\text { Foods exports to more than } 60 \text { countries across the globe including power brands } \\
\text { such as Ceres. }\end{array}$ \\
\hline ORCL & $\begin{array}{l}\text { A leading food producer with a large and growing portfolio of some of South Africa's best } \\
\text { loved brands. }\end{array}$ \\
\hline Sovereing Foods & $\begin{array}{l}\text { An integrated poultry producer with its head office situated in the Eastern Cape in } \\
\text { South Africa. }\end{array}$ \\
\hline The Spar Group Limited & $\begin{array}{l}\text { Distribution centers that supply and service to a big amount of independently owned } \\
\text { SPAR, TOPS at SPAR, Build it, Pharmacy at SPAR and SaveMor stores in Southern Africa. }\end{array}$ \\
\hline Spur & Multi-brand restaurant franchisor with seven brands in South Africa. \\
\hline Taste Holding & $\begin{array}{l}\text { A South African-based management group that owns and licenses a portfolio of franchised } \\
\text { and owned, category specialist and formula driven coffee, QSR and luxury retail brands } \\
\text { housed within two divisions: Food and Luxury Goods. }\end{array}$ \\
\hline Tongaat Hulett & $\begin{array}{l}\text { An agriculture and agro-processing business, focusing on the complementary feed stocks } \\
\text { of sugarcane and maize. }\end{array}$ \\
\hline
\end{tabular}


Table 1. Cont.

\begin{tabular}{cl}
\hline & \multicolumn{1}{c}{ FOREST AND PAPER PRODUCTS } \\
\hline Masonite Africa Limited & The South African market leader in hardboard and soft board. \\
\hline The Newforest Company Group & $\begin{array}{l}\text { An international packaging and paper group located in central Europe, Russia, } \\
\text { the Americas and South Africa. }\end{array}$ \\
\hline Sappi & $\begin{array}{l}\text { A sustainable forestry and value added timber products business with operations in } \\
\text { Rwanda, Uganda and Tanzania and headquarters in Johannesburg, South Africa. }\end{array}$ \\
\hline and bio-refinery solutions to its direct and indirect customer base. & \multicolumn{1}{c}{ TOBACCO pulp, paper based } \\
\hline British American Tobacco South & $\begin{array}{l}\text { It is home to South Africa's top six cigarette brands-market-leader Peter Stuyvesant, } \\
\text { Dunhill, Princeton, Rothmans, Craven A, and Kent-and is the country's leading cigarette } \\
\text { manufacturer and distributor. }\end{array}$ \\
\hline
\end{tabular}

Source: Own work.

\subsection{Qualitative Approach}

This study adopts a qualitative approach to discover the importance of water management reporting in the agro-food sector in South Africa. Thematic content analysis (TCA) has been carried out because it is the most foundational of the qualitative and analytic procedures and informs us of all the qualitative methods [70]. TCA is a descriptive qualitative tool with the aim of transforming data during the data analysis process from description to interpretation. The researcher focuses in two important aspects. First, TCA is about identifying themes and building up the analysis in a cohesive manner to provide a broader understanding of the problem. A satisfactory TCA portrays the thematic content of texts by identifying common topics in the texts selected for analysis. Second, TCA is based on the frequency of occurrence of these themes. In this study, qualitative coding of data was conducted using a method commonly referred to as deductive analysis. It consists of the analysis of the written text from the definition of various groups of categories based on selected criteria supported by the previous academic literature to collect the information systematically. TCA's assumes that frequency-the number of times that a particular code was mentioned within and across texts [71] —is a signal of the importance of the studied subject $[72,73]$. TCA of companies' reports has been a recurrent method used to study CSR and sustainability [74-76] and used to assess social and environmental disclosures of a company [77]. The method has provided valid results for research on sustainability reporting to evaluate the extent of the disclosure on several elements regarding sustainability [74]. The analytic approach was the "computer-assisted NCT analysis" with ATLAS.ti software (7.0, Software Development GmbH, Berlin, Germany) where NCT means noticing things (N), collecting things $(\mathrm{C})$ and thinking about things (T) [78].

\subsection{Research Propositions}

To investigate the extent to which water management is a sensitive topic in CSR disclosure we divided the analysis into three main topics according to prior literature in CRS reporting: organizational integration, quantity and quality of disclosure.

The first topic to be considered in the analysis was the extent to which water sustainability issues were integrated in the report within different levels of the organization. In general terms, being a sustainable organization means that the company strategy is based on a holistic view that integrates and balances the 3Ps (Prosperity, People and Planet) into business decisions, and processes to create added value for all stakeholders [79]. This necessary organizational integration of water management in sustainability has captured the attention of authors such as Hart et al. [80], Pretty et al. [81] or Hopwood et al. [82]. To approach this first topic, we have considered the inclusion of water concerns into three main axes: business strategy, organizational structure, and the business model (BM). When any topic is specifically included in the strategy of a company, it should be reflected in the company vision, mission, values, goals and/or corporate governance [83,84]. In addition, it is well 
known that strategy and structure have to fit in order to get the best organizational results [38,85]. As a result, business structure could incorporate some water concerns by including such concerns in specific job descriptions and organization chart.

Finally, the BM is the tool used to analyze the value creation of a firm, and it also could mediate the transfer of a technology or an idea to the market attending to the value created to the potential customers. It has been demonstrated that water concerns could be a determinant feature of a sustainable BM [10]. To analyze the inclusion of water issues in the business model, the BM Canvas is a good reference. The BM Canvas was created by Osterwalder [86] and improved by Osterwalder et al. [87] and Osterwalder and Pigneur [88]. For analytical purposes, the BM Canvas distinguishes five different key areas in any business. First, the value proposition is the center of the BM and it is designed to serve customers. The second area is the architecture of the relation between the firm and its exchange partners. It considers the customer segment, how a company communicates with and reaches its customer segment to deliver a valued proposition and the types of relationships a company establishes with specific customer segments. Key partners are also important. The third area is the architecture of what a firm is doing. It refers to the key resources and key activities required to make a business model work. The fourth and last point to characterize the BM is the financial area. Revenue stream and cost structure represent the cash a company generates from each customer segment and the cost incurred to operate a BM. In any of these key areas, or in all of them, water management could be integrated as a strategic element for getting a sustainable BM. Based on the above, the first proposition is the following:

Proposition 1. Companies committed to sustainability will disclose information related to the incorporation of water management within different levels in the organization.

The second topic to be considered in our analysis, about the integration of water issues in sustainability reports, is the quantity of disclosure. According to Al-Tuwaijri et al. [89], some authors used space-based measures to try to quantify objectively disclosure extensiveness by counting the number of words, quotations or percentage of total disclosure text devoted to different disclosure areas such as economic, social or environmental issues. However, and considering that space is not the same as subjective content, qualitative content analysis has been used in a broad sense for the study of the content of communication [90], and not only in a narrow sense of counting the number of words or sentences on a particular topic, although it is also a common way of doing disclosure research [91]. Other studies used disclosure indexes based on a content analysis-score [92]. In our case, and in order to analyze in which way companies are addressing the sustainability issue of water, we consider important both, space and content. In line with Lambooy [10], we expect to find content related to the supply chain policy and the target to reduce water use. It is also expected to find commitment with stakeholders and social issues related to water, specific content about the Millennium Development Goal (MDG) number 7, aiming to reduce the proportion of people without sustainable access to safe drinking water and basic sanitation or information related to products and human resources practices for instance. Based on all of the above, the second proposition is the following:

Proposition 2. Companies committed to sustainability will disclose abundant information related to water management.

The third research topic considered in our analysis of water management reporting is the quality of disclosure. Following Solomon [93] and Chauvey et al. [25] this topic focuses on the usefulness of information disclosure for decision making. It is related to the relevance of information, the degree of comparability and transparency. The concept of materiality is central to both risk and audit and is considered one of the important points to take into account according to the GRI guidelines. Comparability of information will enable users to identify and understand similarities, and differences among items. Transparency assumes clarity and verifiability of information presented. Finally, it is also important to know the extent to which companies are willing to disclose negative issues in 
sustainability reports [94-96] or uniquely positive things able to improve reputation. After these considerations, the third proposition is the following:

Proposition 3. Companies committed to sustainability will disclose useful information for water decisions.

In addition, this study examines whether the voluntary water management disclosures included by agro-food companies in South Africa in their sustainability reports are related to social and public exposure. According to Patten [97], it is argued that social and environmental disclosures could be being used by agro-food companies as a means of addressing the exposure firms face with regard to the social pressure as intensive water consumers and highly potential polluters. Consequently, assuming that as much social and public exposure of a company, more and better CSR disclosure, the last proposition for the analysis is the following:

Proposition 4. Companies with high levels of social and public exposure will have more and better water management disclosure than others.

\subsection{Procedure}

According to the previous literature review, a deductive approach has been applied. A step by step model of the process is shown in Figure 1. A deductive category application works based on a prior theoretical definition of the main aspects of the analysis, bringing them in connection with the texts. Collecting codes in a coding agenda is the formative way for checking reliability. Writing categories and codes definitions are an important part of the analytical process [98].

Then, working through the texts new codes could merge, and if necessary they are accepted and integrated the coding agenda, being considered as one more output of the research and an adaptation of previous theory to real case-studies. Coding the text could be interpreted as a summative check of reliability. Thus, after the first round working through the reports and focused on the main categories and sub-categories, successive rounds came up. Finally, we reached the point in which we were confronted a phenomenon of repetition attaining theoretical saturation. The process of coding generates a great number of links between individual codes and the data segments they encode.

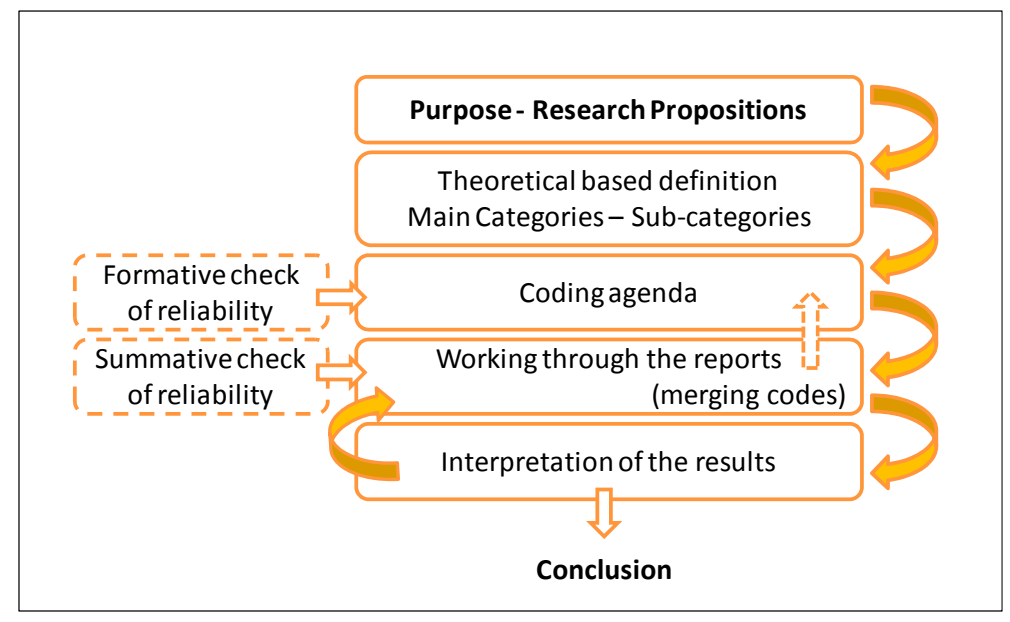

Figure 1. Deductive step model (Source: Own work).

Three different blocks of codes were created to assess propositions from 1 to 3 . Proposition 4 was addressed by using the same codes Table 2 shows the final coding agenda developed for this study to guarantee both, formative and summative check of reliability. The interpretation of results 
presented in the form of conceptual maps (called networks views) gave us the answer to the research propositions and the conclusion of the qualitative study.

Table 2. Coding Agenda.

\begin{tabular}{|c|c|c|}
\hline \multicolumn{2}{|r|}{ Codes and Definitions } & Authors \\
\hline \multicolumn{3}{|l|}{ Codes Related to Proposition 1} \\
\hline \multicolumn{3}{|c|}{1 Organizational Integration-Incorporation of water sustainability issues within different levels in the organization. } \\
\hline 1.1 Business Strategy & $\begin{array}{l}\text { Water management included specifically in the } \\
\text { corporate strategy. Water issues included in the } \\
\text { company mission, values, corporate governance }\end{array}$ & $\begin{array}{l}\text { Collins et al. } \\
\text { Thorne McAlister and Ferrell }\end{array}$ \\
\hline 1.2 Structure & $\begin{array}{l}\text { Water concerns included in some positions, in job } \\
\text { descriptions or organization chart }\end{array}$ & $\begin{array}{l}\text { Mintzberg } \\
\text { Johnson and Scholes }\end{array}$ \\
\hline 1.3 Business Model & $\begin{array}{l}\text { To analyze the value creation of a firm, and it also } \\
\text { could mediate the transfer of a technology or an idea } \\
\text { to the market attending to the value created to the } \\
\text { potential customers }\end{array}$ & Lambooy \\
\hline 1.3.1 Value proposition & Creating value for customers & \multirow{4}{*}{ Osterwalder } \\
\hline $\begin{array}{l}\text { 1.3.2 Architecture between the } \\
\text { firm and key partners }\end{array}$ & $\begin{array}{l}\text { Customer segment, channels and customer } \\
\text { relationship, key partners, commitment, compliance }\end{array}$ & \\
\hline $\begin{array}{l}\text { 1.3.3 Architecture of what the } \\
\text { firm is doing }\end{array}$ & Key resources and key activities & \\
\hline 1.3.4 Financial aspects & Revenue stream and cost structure & \\
\hline \multicolumn{3}{|c|}{ Codes related to Proposition 2 and 4} \\
\hline \multicolumn{3}{|c|}{2 Information Quantity_Amount of disclosure, space and content } \\
\hline 2.1 Space & $\begin{array}{l}\text { Presence in the report of water related issues (more } \\
\text { than average, average, less than average, } \\
\text { no presence) }\end{array}$ & Al-Tuwaijri et al. \\
\hline 2.2 Content & $\begin{array}{l}\text { Responsible Company Activity regarding } \\
\text { water issues }\end{array}$ & \multirow{7}{*}{ Jose and Lee } \\
\hline 2.2.1 Cleaner Production & $\begin{array}{l}\text { Supply chain policy and watershed management. } \\
\text { Target to reduce water use, use of chemicals and } \\
\text { generation of waste }\end{array}$ & \\
\hline 2.2.2 MDG7 & $\begin{array}{l}\text { Efforts to attain the millennial goal of safe } \\
\text { drinking water }\end{array}$ & \\
\hline 2.2.3 Community Concerns & $\begin{array}{l}\text { Present local activity, engagement, } \\
\text { community involvement or consult with } \\
\text { community (commitment) }\end{array}$ & \\
\hline 2.2.4 Products & $\begin{array}{l}\text { Responsible products and fair business practices } \\
\text { related to water }\end{array}$ & \\
\hline 2.2.5 Human Resources (HR) & $\begin{array}{l}\text { Actions to sensitize workforce and management for } \\
\text { environmental problems related to water caused by } \\
\text { the enterprise, including health and safety }\end{array}$ & \\
\hline 2.2.6 Image & $\begin{array}{l}\text { Presence in the report of images related to } \\
\text { water issues }\end{array}$ & \\
\hline
\end{tabular}

Codes related to Proposition 3 and 4

3 Information Quality-Qualitative characteristic for decision useful information

3.1 Relevance of information. Capacity of making a difference in the decisions made by both the organization and its users

\begin{tabular}{ll}
\hline 3.1.2 Identification & Identification of stakeholders and their needs \\
\hline 3.1.3 Dialog & Dialog with stakeholders to define their needs \\
\hline 3.1.4 Materiality & Analysis of risks factors specific to the company \\
\hline $\begin{array}{l}\text { 3.2 Comparability. Qualitative characteristic that enables users to identify and } \\
\text { understand similarities in, and differences among items }\end{array}$
\end{tabular}


Table 2. Cont

\begin{tabular}{|c|c|c|}
\hline \multicolumn{2}{|r|}{ Codes and Definitions } & \multirow[t]{2}{*}{ Authors } \\
\hline 3.2.1 Temporal & Temporal features and comparisons & \\
\hline 3.2.2 Others & $\begin{array}{l}\text { Comparisons with other companies or to } \\
\text { external norms }\end{array}$ & \multirow{8}{*}{$\begin{array}{l}\text { Solomon } \\
\text { Chauvey et al. }\end{array}$} \\
\hline \multicolumn{2}{|c|}{$\begin{array}{l}\text { 3.3 Transparency. Clarity and verifiability of information presented regarding the } \\
\text { company activity per type of water use }\end{array}$} & \\
\hline $\begin{array}{l}\text { 3.3.1 Consumer and } \\
\text { industrial use }\end{array}$ & $\begin{array}{l}\text { Clear information about domestic use of tap water, } \\
\text { ground water (high impact), industrial use (row } \\
\text { materials, cooling) }\end{array}$ & \\
\hline 3.3.2 Treated water & Clear information about recycled water & \\
\hline 3.3.3 Emissions & Clear information about emissions into water & \\
\hline \multirow{3}{*}{$\begin{array}{l}\text { 3.3.4 Methods of elaboration, } \\
\text { calculation and/or reporting } \\
\text { mechanisms }\end{array}$} & Methods of elaboration & \\
\hline & Calculation & \\
\hline & Reporting mechanisms & \\
\hline
\end{tabular}

Source: Own work.

\section{Results}

Given the exploratory nature of this study in the absence of consolidated models accepted by the scientific community for our purposes, we have decided to show results in visual images. According to Friese [78], the network views obtained with ATLAS.ti have the power to activate different regions in our brains and stimulate us to think in different and creative ways to understand the big picture of any research question and to find the right answer.

Networks have the ability to show in just one view relationships between codes. They also show selected quotations as empirical evidences, pictures to complement the conceptual map and to help understand the relationships and quantitative information because each code appears associated with other codes in a logical manner. The two numbers that appear close to each code express the groundedness (frequency of occurrence) and the saturation (or number of links with other codes).

The network view in Figure 2 graphically shows the answer to the first proposition about the consideration of water issues at the organizational level. This network explains the relative integration of water concerns in the business strategies, structures and business models of the agro-business analyzed. The colored boxes show codes and the color depends on groundedness and saturation. The blue color means less groundness. The color changes when the code increases the number of quotations. It is remarkable the code compliance, in pale green. It is the code showing the highest groundedness. The clear boxes show selected quotations. They are good examples to show the kind of information found in the sustainability reports belonging to one or more categories and codes from Table 2.

For instance, as part of the BM, and according to the results, we have recollected 47 quotations referring the inclusion of water issues in the sustainability report which motivation was to comply with the law (coded compliance). Good examples are the following quotations: Water is extracted from the Bushman' River in compliance with the permit from the Department of Water Affaires or The water is sampled and tested monthly as per the requirements of the Department of Water and Sanitation. These quotations, considered evidences in qualitative analysis, demonstrate that the company does not feel morally obliged but it does it because it was compulsory to do it. In line with Jones [99] and Chauvey et al. [25], our results indicate that, while various factors positively influence voluntary environmental management and water management disclosure in sustainability reports, regulatory pressures are clearly the most important.

Another important element integrated in the agro-business models analyzed is the consideration of water as part of the architecture of what the firm is doing (25 quotations as key resource and 
20 as key activity). Consequently, water is also relevant for the cost structure of agro-business operations (18 evidences).

We have also found clear evidence of the importance of water in businesses strategy, especially in their goals and values with 27 quotations. Companies recognize that the availability and quality of water is increasingly becoming a strategic sustainability issue requiring management. Agro-business view sustainable water management as integral to the success of their business. These companies understand that they operate in a world of constrained water resources, facing environmental and social challenges and one of them has highlighted the following with the realities of water scarcity increasingly being felt in South Africa we know we have a responsibility to work to reduce water use.

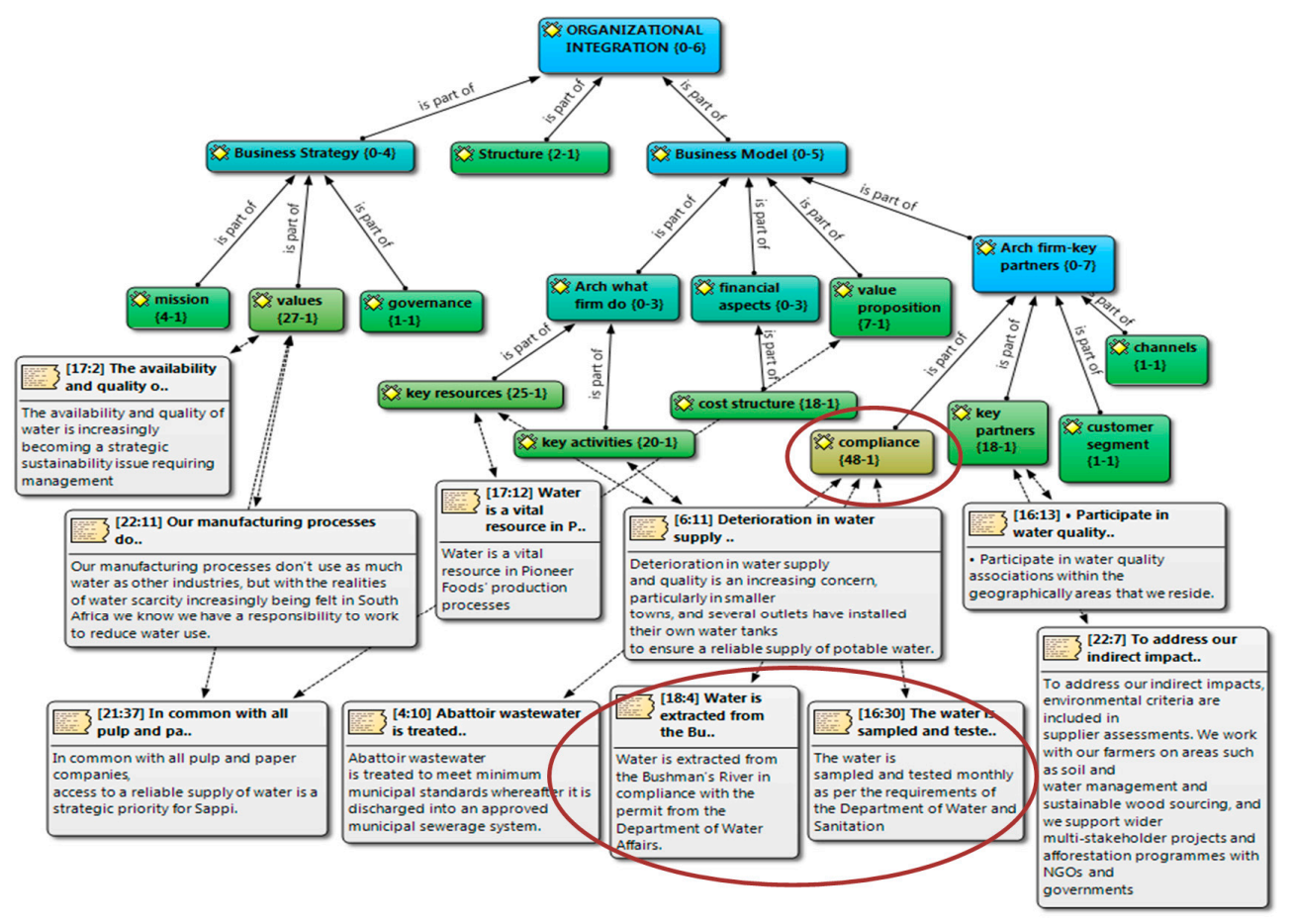

Figure 2. Organizational Integration (Source: Own work).

Moving from quantity to content issues in order to answer the second proposition of this study, important information has been found. In South Africa the abstraction of water, discharge of effluent and management of forests are all regulated under a license system in which first allocations go to, among other things, human consumption. Before allocations are made to agriculture, industry and forestry. Because of this fact, and related to water management disclosure, cleaner production is the principal topic in sustainability reports ( 89 quotations) followed by related topics represented by the codes compliance, materiality and consumer use (Figure 3). Almost all companies express they have made some progress in reducing water-usage in South Africa. Even acknowledging that it is very important for the country given the fact that South Africa is a water-stressed area, they also assume that they need to continue improving. Quotations such as reducing 30\% water consumption or ensuring sustainable consumption and production patterns by producing more food with less water are very good examples of the content found in these reports.

Social commitment related to water is also an important topic in these reports with 29 quotations of this. For instance, the round about water project developed by SPAR is a group project centered on places where children congregate. Merry-go-rounds are erected where the children play and in the process of playing they pump water into reservoirs. Consequently, CSR has economic and environmental purposes but social purposes as well in the companies analyzed. 


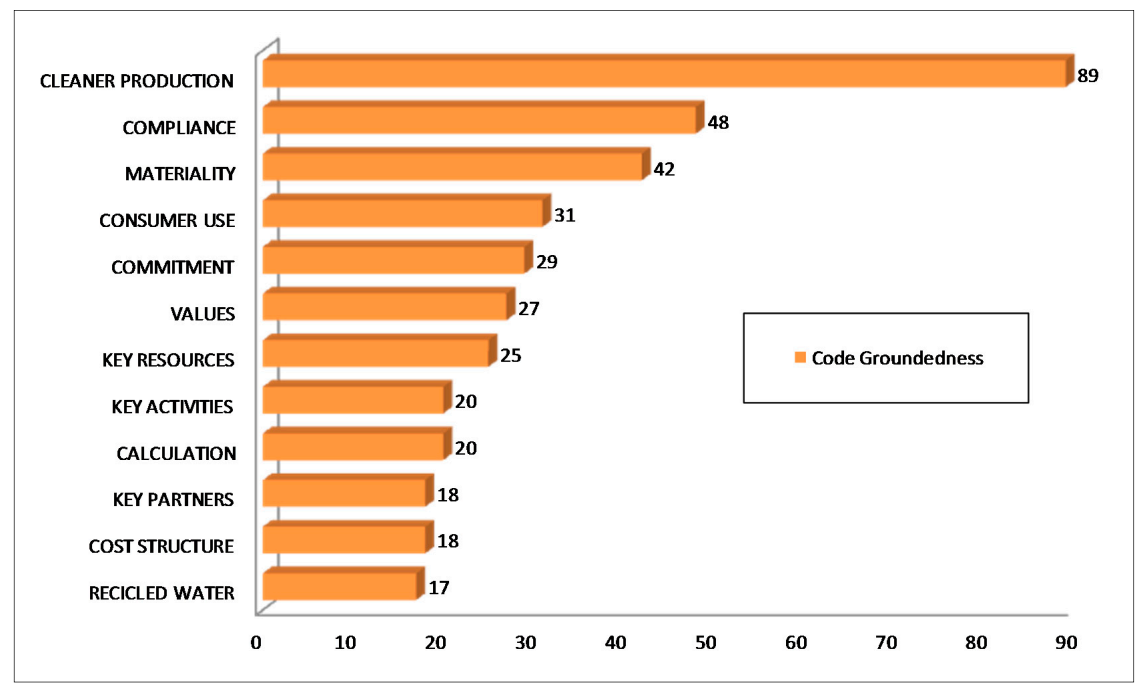

Figure 3. Main topics included in sustainability reports related to water management. (Source: Own work).

Figure 4 visually shows the frequency of water topics identified in companies' reports. It is noticeable that five companies (out of twenty-two) are the water disclosure champions in this study, with the highest level of disclosure. Sappi, Tongaat Hulett, RCL, Oceana and Distell have reported more information about water than the average.

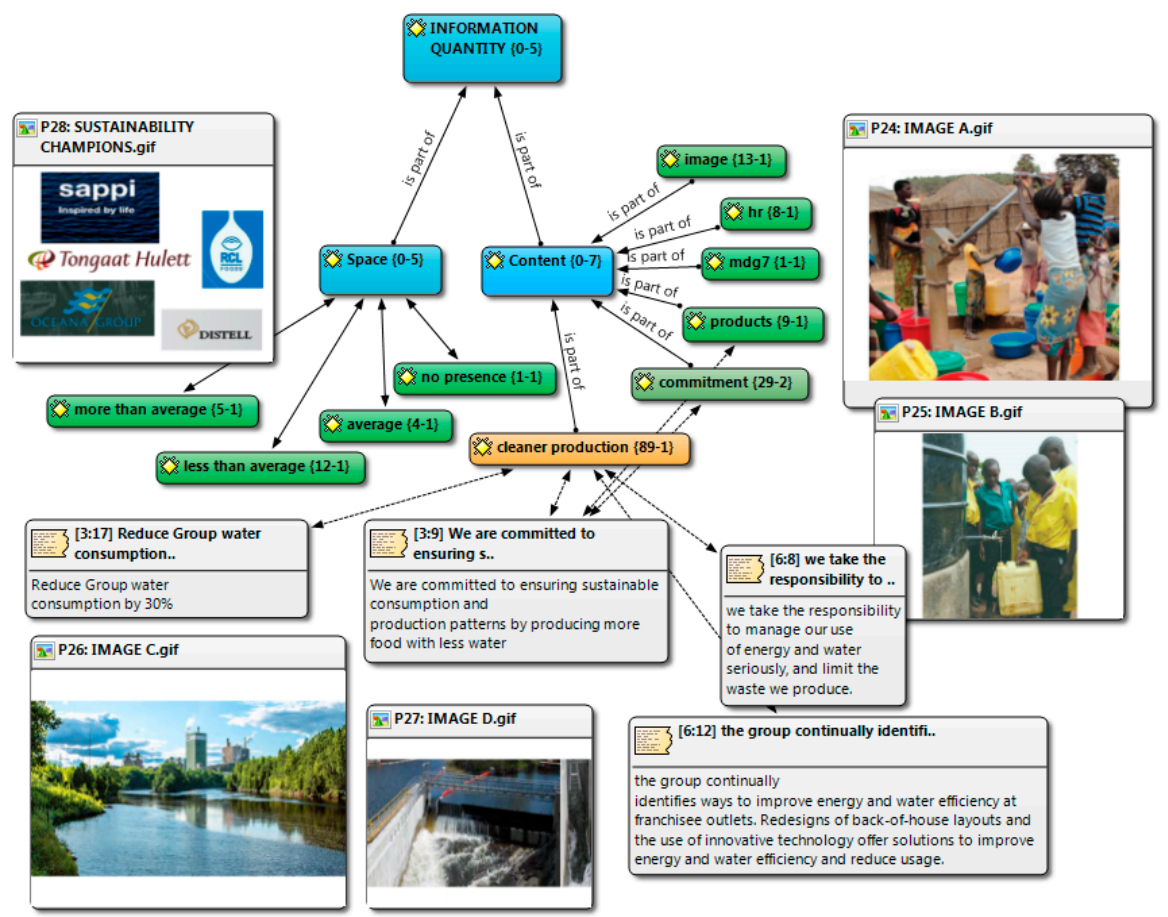

Figure 4. Information quantity (Source: Own work).

Related to the third proposition, the quality of information is shown in Figure 5. Although sustainability reports raise doubts on the reliability of the published information [100], our results show that the attributes of comparability, relevance and transparency are equilibrated. The most noticeable result in this respect is the clear consideration of water as a material pillar of the agro-business sector with 42 quotations. The sector is aware of their dependence on water for agricultural production, raw materials and/or for production processes. Companies recognize that water management will remain 
one of the most critical challenges for sustainable food production. Therefore, we found very few cases reporting negative issues. Unfortunately, the recommendable neutrality required for transparency purposes and legitimacy consolidation - previously defined as disclosure of negative performance information-is not a characteristic of the analyzed sustainability reports.

Finally, to complement the information already provided, Figure 6 shows the answer to the fourth proposition to discover whether companies with the highest level of disclosure in water issues are the most social and publicly exposed trying to improve their reputation thought reporting excellence. As we can observe Sappi, from the very exposed sector of forest and paper productions, is on the top of our ranking with 68 quotations in its sustainability report related to water management information.

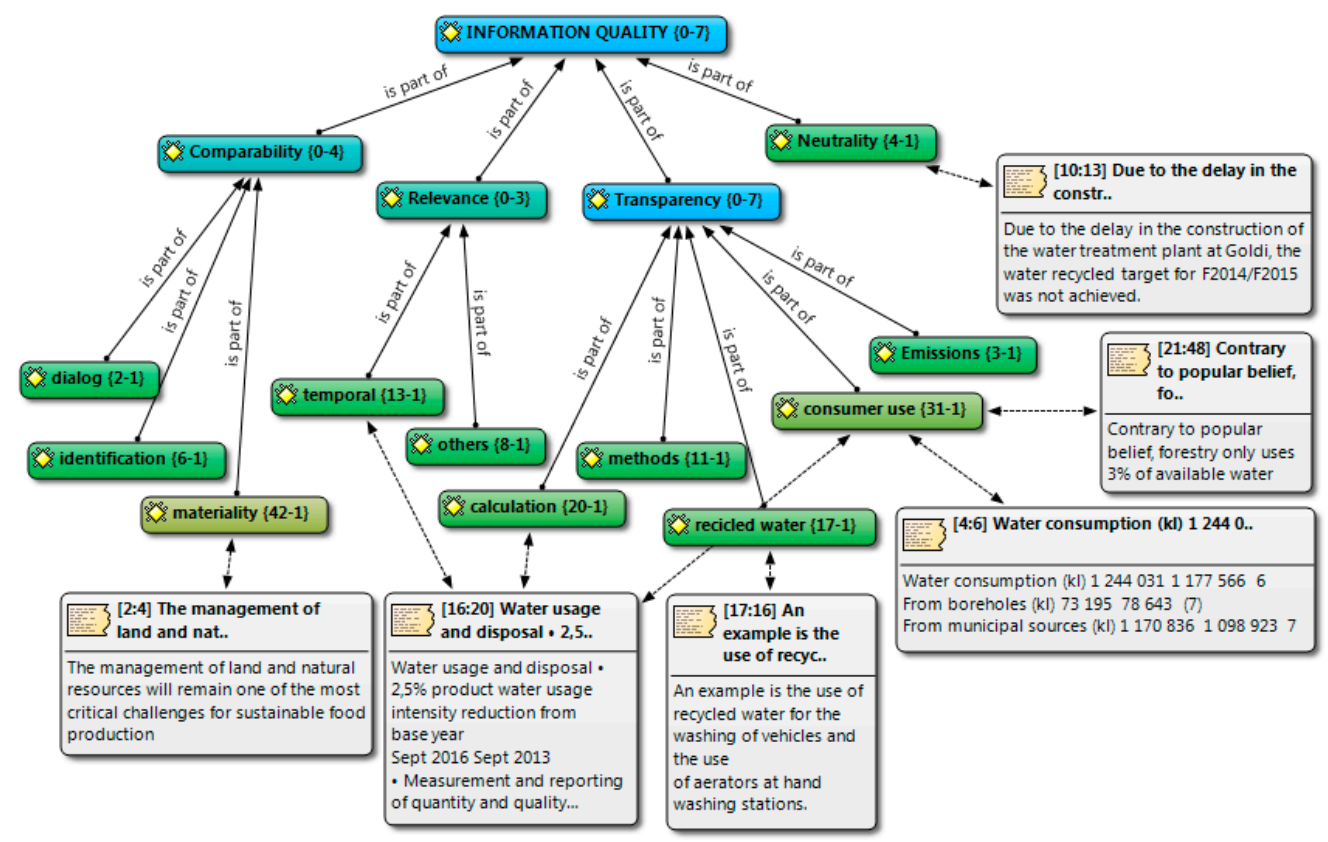

Figure 5. Information quality (Source: Own work).

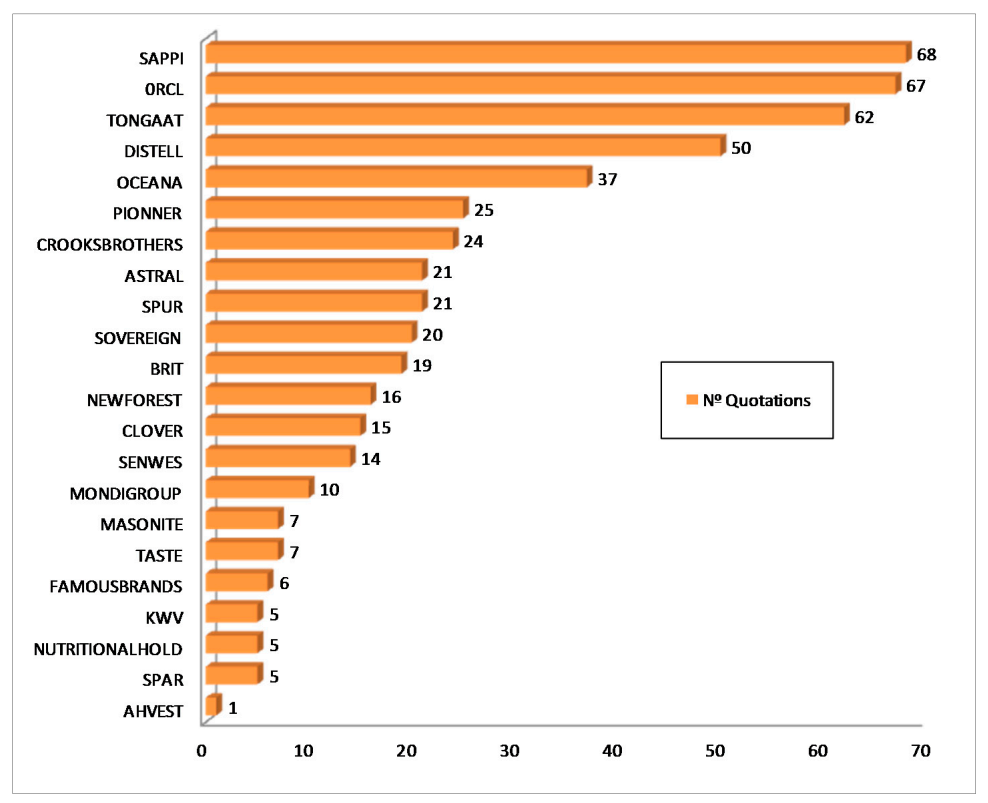

Figure 6. Level of information disclosed related to water issues by company. (Source: Own work). 


\section{Discussion and Final Remarks}

Agro-food companies that compete globally are exposed to social and environmental pressure and are progressively more required to commit to and report on the overall operations by showing sustainability initiatives. According to the reports analyzed, the main contribution of this study was to verify that South African agro-food companies are relatively committed to sustainability disclosure information. In line with Fisk [79], these companies are also committed to creating value for all their stakeholders by conducting sustainable businesses through ethical dealings, protecting the environment and contributing to the socio-economic development of their employees and societies in which they conduct business. Specifically, all companies in the sample incorporate water management within different levels in the organization but with different degrees of importance for the business strategy. In this respect, in line with Lambooy [10], the more noticeable was the inclusion of water issues in business models. In our opinion, such inclusion should be considered one of the best practices in the field. For instance, the company Pioneer considers water as a vital resource for its production processes and its management is in the core business. In the same line, Sappi is developing and maintaining a strong brand identity related to sustainability.

This work also contributes to complement with new insights previous approaches to corporate social and environmental reporting in South Africa from De Villers [60,62], De Villers and colleagues [61,63] and other related works [64,65]. In this respect, it is remarkable how compliance in South Africa is still inextricably linked to organizational governance although the analysis also showed that compliance is starting to be linked with CSR strategies. Compliance was most often identified as the elimination of legal risks in the organization. Although compliance is focused primarily on aspects of risk management, primarily legal, here it was closely associated with the culture of sustainable organization. In general, it was mainly with respect to duly fulfill the duties of the company, ensuring compliance with the law in benefit to the fundamental interests of the country. In addition, it was noted that the ethical culture of the organization should include standards related to the need to avoid illegal activities related to water management. The foundation of the ethical culture of the organization should always include universal values such as honesty, reliability, honoring commitments, social responsibility and justice. In this context, effective functioning of the compliance mechanism is dependent on taking into account the entire spectrum of the above-mentioned aspects of the ethical culture of the organization.

The companies Sappi, Tongaat Hulett, RCL Foods, Oceana and Distell reported more information about water management than the average in the sample and because of that they could be considered the best practices in reporting water issues. In fact, their sustainability reports are very good tools for communicating sustainability concerns. For instance, the RCL Foods passion statement is to provide more food, to more people, more often. They believe that by nourishing people while sustaining their resources, everyone wins. These companies were revealed in their sustainability reports to be creative, imaginative and resourceful in seeking solutions for business challenges related to water management and meeting customer needs. Specifically, Sappi, showed more and better water management disclosure than the others companies and belongs to the subsector of forest and paper production. That is an important fact that demonstrates how companies with a high level of social and public exposure are even more committed to sustainability reporting than others. Consequently, and based on the Legitimacy theory, we share with Perrini [32] and Brown et al. [36] that other companies could follow this example to improve corporate reputation.

Through the analysis of the information provided by the selected companies in their reports, we consider that CSR and sustainable water management are in fact relevant topics for the sector. Although the reports analyzed were from companies with similar sizes and characteristics, some differences are noticeable between them. The core ideas and fundamental messages of this research are the following.

CSR reporting rates in South Africa are really high because the practice is mandatory. Although there is not any specific mandate to report about water management, the integration of water issues has been demonstrated in the sustainability reports analyzed here in the agro-food sector. 
That is responding to the urgency of the global threats in the sector, both social and environmental, especially in this country that is extremely affected by water scarcity, whose agro-food businesses are at risk.

The quantity of water management information provided by companies depends on the company interest and marketing strategy but does not depend on the agriculture, food and beverages, forest and paper or tobacco subsectors. Even considering the high level of public exposure of companies belonging to different subsectors such as forest, that is not a reason to avoid disclosing their information, rather the opposite.

In relation to the quality of disclosure, the results reveal that companies include in their reports useful information about water management for their stakeholders, especially about cleaner production, but compliance is their motivation, not ethical spirit.

In general, and following the trend previously observed in other academic works reviewed, the purpose of the information provided by the reports analyzed in this is work, was mostly to communicate positive issues, avoiding disclosing negative actions that could damage their corporate reputation.

To conclude, the aim of our study was to shed light on the relative importance of water issues in sustainability in disclosure agro-business' reports in South Africa. General pragmatic advice for practitioners could derive from the research results as more companies should want to follow the example to disclose relevant and completed economic, social and environmental information related to water to gain the needed legitimization of their actions.

Acknowledgments: The authors are grateful to the Regional Government of Extremadura, in Spain (Junta de Extremadura) for supporting the research groups at the University of Extremadura. The research behind the article was possible thanks to the collaboration of the European Project (IRSES-GA-2013-612686-ECODRY). We did not have received any funds for covering the cost to publish in open access.

Author Contributions: M. Isabel Sánchez-Hernandez coordinated the article, designed the research, analyzed the data and wrote the final version manuscript. Rafael Robina-Ramírez contributed to the literature review and philosophical analysis of the ethical arguments related to water management. Willem De Clercq contributed to the analysis of the technical aspects related to water management.

Conflicts of Interest: The authors declare no conflict of interest.

\section{References}

1. Rijsberman, F.R. Water scarcity: Fact or fiction? Agric. Water Manag. 2006, 80, 5-22. [CrossRef]

2. Zeng, Z.; Liu, J.; Savenije, H.H. A simple approach to assess water scarcity integrating water quantity and quality. Ecol. Indic. 2013, 34, 441-449. [CrossRef]

3. Motsoeneng, M. Monitoring and Evaluating the Progressive Realization of the Right to Water and Sanitation in South Africa. Studies in Poverty and Inequality Institute, Working Paper 12. Unpublished work. 2016. Available online: https://spii.org.za/wp.../Policy-brief-2_Monitoring-rights_Healthcare.pdf (accessed on 28 October 2017).

4. United Nations. International Decade for Action. Water for Life 2005-2015. 2014. Available online: www.un.org (accessed on 22 February 2017).

5. Ortiz-Correa, J.S.; Resende Filho, M.; Dinar, A. Impact of access to water and sanitation services on educational attainment. Water Resour. Econ. 2016, 14, 31-43. [CrossRef]

6. Rothert, S. Water conservation and demand management potential in southern Africa: An untapped river. Int. J. Water 2000, 1, 118-144. [CrossRef]

7. WBCSD. Water Facts and Trends. World Business Council on Sustainable Development: Washington, DC, USA, 2005. Available online: https://www.sswm.info/sites/default/files/reference_attachments/ WBCSD\%202009\%20Water\%20Facts\%20and\%20Trends.pdf (accessed on 28 October 2017).

8. Blignaut, J.; Ueckermann, L.; Aronson, J. Agriculture production's sensitivity to changes in climate in South Africa. S. Afr. J. Sci. 2009, 105, 61-68.

9. Visser, W. Sustainability reporting in South Africa. Corp. Environ. Strategy 2002, 9, 79-85. 
10. Lambooy, T. Corporate social responsibility: Sustainable water use. J. Clean. Prod. 2011, 19, $852-866$. [CrossRef]

11. Bebbington, J.; Gray, R.; Larrinaga, C. Environmental and social accounting in Europe. Eur. Acc. Rev. 2000, 9, 3-6.

12. Maignan, I.; Ralston, D.A. Corporate social responsibility in Europe and the US: Insights from businesses' self-presentations. J. Int. Bus. Stud. 2002, 33, 497-514. [CrossRef]

13. Matten, D.; Moon, J. “Implicit” and "explicit” CSR: A conceptual framework for a comparative understanding of corporate social responsibility. Acad. Manag. Rev. 2008, 33, 404-424. [CrossRef]

14. Rock, M.T. Pathways to Industrial Environmental Improvement in the East Asian Newly Industrialising Economies. Bus. Strategy Environ. 2002, 11, 90-102. [CrossRef]

15. Welford, R. Corporate social responsibility in Europe, North America and Asia: 2004 survey results. J. Corp. Citizsh. 2005, 17, 33-52. [CrossRef]

16. Fifka, M.S. Corporate responsibility reporting and its determinants in comparative perspective-A review of the empirical literature and a meta-analysis. Bus. Strategy Environ. 2013, 22, 1-35. [CrossRef]

17. Visser, W. Corporate Social Responsibility in Developing Countries. In The Oxford Handbook of Corporate Social Responsibility; Crane, A., Matten, D., McWilliams, A., Moon, J., Siegel, D.S., Eds.; Oxford University Press: New York, NY, USA, 2008.

18. Idemudia, U. Corporate social responsibility and developing countries: Moving the critical CSR research agenda in Africa forward. Prog. Dev. Stud. 2011, 11, 1-18. [CrossRef]

19. O'Connor, M.; Spangenberg, J.H. A methodology for CSR reporting: Assuring a representative diversity of indicators across stakeholders, scales, sites and performance issues. J. Clean. Prod. 2008, 16, 1399-1415. [CrossRef]

20. García-Sánchez, I.M.; Rodríguez-Ariza, L.; Frías-Aceituno, J.V. The cultural system and integrated reporting. Int. Bus. Rev. 2013, 22, 828-838. [CrossRef]

21. Vörösmarty, C.J.; McIntyre, P.B.; Gessner, M.O.; Dudgeon, D.; Prusevich, A.; Green, P.; Glidden, S.; Bunn, S.E.; Sullivan, C.A.; Liermann, C.R.; et al. Global threats to human water security and river biodiversity. Nature 2010, 467, 555-561. [CrossRef] [PubMed]

22. CERES, The CERES roadmap for sustainability. A Strategic Vision and Practical Framework for Sustainable Corporations in the 21th Century Economy. 2016. Available online: www.ceres.org (accessed on 12 February 2017).

23. Larrinaga, C.; Carrasco, F.; Correa, C.; Llena, F.; Moneva, J.M. Accountability and accounting regulation: The case of the Spanish Disclosure Standard. Eur. Acc. Rev. 2002, 11, 723-740. [CrossRef]

24. Delbard, O. CSR legislation in France and the European regulatory paradox: An analysis of EU CSR policy and sustainability reporting practice. Corp. Gov. 2008, 8, 397-405. [CrossRef]

25. Chauvey, J.N.; Giordano-Spring, S.; Cho, C.H.; Patten, D.M. The normative and legitimacy of CSR disclosure: Evidence from France. J. Bus. Ethics 2015, 130, 789-803. [CrossRef]

26. O'Donovan, G. Environmental disclosures in the annual report: Extending the applicability and predictive power of legitimacy theory. Acc. Audit. Account. J. 2002, 15, 344-371. [CrossRef]

27. Cormier, D.; Magnan, M.; Van Velthoven, B. Environmental disclosure quality in large German companies: Economic incentives, public pressures or institutional conditions? Eur. Acc. Rev. 2005, 14, 3-39. [CrossRef]

28. Suchman, M.C. Managing legitimacy: Strategic and institutional approaches. Acad. Manag. Rev. 1995, 20, 571-610.

29. Magness, V. Strategic posture, financial performance and environmental disclosure: An empirical test of legitimacy theory. Acc. Audit. Account. J. 2006, 19, 540-563. [CrossRef]

30. Integrated Reporting Committee of South Africa. 2017. Available online: www.integratedreportingsa.org (accessed on 10 February 2017).

31. De Villiers, C.; Rinaldi, L.; Unerman, J. Integrated Reporting: Insights, gaps and an agenda for future research. Acc. Audit. Account. J. 2014, 27, 1042-1067. [CrossRef]

32. Perrini, F. The practitioner's perspective on non-financial reporting. Calif. Manag. Rev. 2006, 48, 73-103. [CrossRef]

33. Kolk, A. Trends in sustainability reporting by the Fortune Global 250. Bus. Strategy Environ. 2003, 12, $279-291$. [CrossRef]

34. Cheng, B.; Ioannou, I.; Serafeim, G. Corporate social responsibility and access to finance. Strategy Manag. J. 2014, 35, 1-23. [CrossRef] 
35. Connelly, J.T.; Limpaphayom, P. Environmental reporting and firm performance: Evidence from Thailand. J. Corp. Citizsh. 2004, 13, 137-149.

36. Brown, H.S.; de Jong, M.; Levy, D.L. Building institutions based on information disclosure: Lessons from GRI's sustainability reporting. J. Clean. Prod. 2009, 17, 571-580. [CrossRef]

37. Freeman, R.E. Strategic Management: A Stakeholder Approach; Pitman Publishing: London, UK, 1984.

38. Johnson, G.; Scholes, K. Exploring Corporate Strategy; Pearson Education: Harlow, UK, 2002.

39. Ruf, B.M.; Muralidhar, K.; Brown, R.M.; Janney, J.J.; Paul, K. An empirical investigation of the relationship between change in corporate social performance and financial performance: A stakeholder theory perspective. J. Bus. Ethics 2001, 32, 143-156. [CrossRef]

40. Handy, C. What's a Business For? Harv. Bus. Rev. 2002, 80, 49-55. [PubMed]

41. Sánchez-Hernandez, M.I.; Bañegil Palacios, T.; Sanguino-Galván, R. Competitive Success in Responsible Regional Ecosystems: An Empirical Approach in Spain Focused on the Firms' Relationship with Stakeholders. Sustainability 2017, 9, 449. [CrossRef]

42. Geldenhuys, D. The weak domestic base of South Africa's good global citizenship. S. Afr. J. Int. Aff. 2015, 22, 411-428. [CrossRef]

43. De Wet, H. The Environmental Handbook: A Guide to Green Business in South Africa; Trialogue: Cape Town, South Africa, 2010.

44. Triebel, C.; Van Niekerk, P.H. The Water Supply Systems in South Africa. In Large Dams and Water Systems in South Africa; The South African National Committee on Large dams: Pretoria, South Africa, 1994.

45. Funke, N.; Nortje, K.; Findlater, K.; Burns, M.; Turton, A.; Weaver, A.; Hattingh, H. Redressing inequality: South Africa's new water policy. Environ. Sci. Policy Sustain. Dev. 2007, 49, 10-23. [CrossRef]

46. The World Bank. Report on the Status of Disaster Risk Reduction in Africa; The World Bank: Washington, DC, USA, 2010.

47. Falkenmark, M. Rapid population growth and water scarcity: The predicament of tomorrow's Africa. Popul. Dev. Rev. 1990, 16, 81-94. [CrossRef]

48. Jacobsen, M.; Webster, M.; Vairavamoorthy, K. The Future of Water in African Cities: Why Waste Water? The World Bank: Washington, DC, USA, 2012.

49. Stikker, A. Water today and tomorrow: Prospects for overcoming scarcity. Futures 1998, 30, 43-62. [CrossRef]

50. Selborne, L. The Ethics of Freshwater Use: A Survey. UNESCO, 2000. Available online: http://unesdoc. unesco.org/images/0012/001220/122049e.pdf (accessed on 28 October 2017).

51. Debbané, A.M.; Keil, R. Multiple disconnections: Environmental justice and urban water in Canada and South Africa. Space Polity 2004, 8, 209-225. [CrossRef]

52. Hill, J. Thinking about a more sustainable business: An indicators approach. Corp. Environ. Strategy 2001, 8, 30-38. [CrossRef]

53. Fresner, J.; Engelhardt, G. Experiences with integrated management systems for two small companies in Austria. J. Clean. Prod. 2004, 12, 623-631. [CrossRef]

54. Moxon, J.; Strachan, P. Green Teams; Greenleaf Publishing: Sheffield, UK, 1998.

55. Beard, C.; Rees, S. Green teams and the management of environmental change in a UK county council. Environ. Manag. Health 2000, 11, 27-38. [CrossRef]

56. Zadek, S. The path to Corporate Responsibility. Harv. Bus. Rev. 2004, 82, 125-132. [PubMed]

57. Gallardo-Vázquez, D.; Sanchez-Hernandez, M.I. Measuring corporate social responsibility for competitive success at a regional level. J. Clean. Prod. 2014, 72, 14-22. [CrossRef]

58. Gumbo, B.; Mlilo, S.; Broome, J.; Lumbroso, D. Industrial water demand management and cleaner production potential: A case of three industries in Bulawayo, Zimbabwe. Phys. Chem. Earth Parts A/B/C 2003, 28, 797-804. [CrossRef]

59. Lehmann, R.J.; Reiche, R.; Schiefer, G. Future internet and the agri-food sector: State-of-the-art in literature and research. Comput. Electron. Agric. 2012, 89, 158-174. [CrossRef]

60. De Villiers, $C$. The decision by management to disclose environmental information: A research note based on interviews. Meditari Account. Res. 1999, 7, 33-48.

61. De Villiers, C.; Barnard, P. Environmental Reporting in South Africa from 1994 to 1999: A research note. Meditari Account. Res. 2000, 8, 15-23. [CrossRef]

62. De Villiers, C. Why do South African companies not report more environmental information when managers are so positive about this kind of reporting? Meditari Account. Res. 2003, 11, 11-23. [CrossRef] 
63. De Villiers, C.; Van Staden, C.J. Can less environmental disclosure have a legitimising effect? Evidence from Africa. Account. Organ. Soc. 2006, 31, 763-781. [CrossRef]

64. Dawkins, C.; Ngunjiri, F.W. Corporate Social Responsibility Reporting in South Africa. J. Bus. Commun. 2008, 45, 286-307. [CrossRef]

65. Mitchell, C.G.; Hill, T. Corporate Social and Environmental Reporting and the Impact of Internal Environmental Policy in South Africa. Corp. Soc. Responsib. Environ. Manag. 2009, 16, 48-60. [CrossRef]

66. Gray, R.H.; Bebbington, K.J. Accounting for the Environment, 2nd ed.; Sage: London, UK, 2001.

67. KPMG. Currents of change. The KPMG Survey of Corporate Responsibility Reporting 2015. Available online: https:/ / home.kpmg.com (accessed on 23 February 2017).

68. Patton, M.Q. Qualitative Research E Evaluation Methods: Integrating Theory and Practice, 4th ed.; Sage: Los Angeles, CA, USA, 2015.

69. Johnson, P. The financial stability of sustainable organizations. J. Bus. Econ. Res. 2012, 9, 65-74.

70. Sandelowski, M.; Barroso, J. Classifying the findings in qualitative studies. Qual. Health Res. 2003, 13, 905-923. [CrossRef] [PubMed]

71. Lee, T.W.; Mitchell, T.R.; Sablynski, C.J. Qualitative research in organizational and vocational psychology, 1979-1999. J. Vocat. Behav. 1999, 55, 161-187. [CrossRef]

72. Guthrie, J.; Petty, R.; Yongvanich, K.; Ricceri, F. Using content analysis as a research method to inquire into intellectual capital reporting. J. Intellect. Cap. 2004, 5, 282-293. [CrossRef]

73. Krippendorff, K. Content Analysis: An Introduction to Its Methodology; Sage: London, UK, 2004.

74. Tang, L.; Li, H. Corporate Social Responsibility communication of Chinese and global corporations in China. Public Relat. Rev. 2009, 35, 199-212. [CrossRef]

75. Metaxas, T.; Tsavdaridou, M. CSR in metallurgy sector in Greece: A content analysis. Resour. Policy 2013, 38, 295-309. [CrossRef]

76. Horneaux-Junior, F.; Galleli-Dias, B.; Gallardo-Vázquez, D.; Sánchez-Hernández, M.I. Strategic Aspects in Sustainability Reporting in Oil \& Gas Industry: The comparative case-study of Brazilian Petrobras and Spanish Repsol. Ecol. Indian J. 2017, 72, 203-214.

77. Milne, M.J.; Adler, R.W. Exploring the reliability of social and environmental disclosures content analysis. Acc. Audit. Account. J. 1999, 12, 237-256. [CrossRef]

78. Friese, S. Qualitative Data Analysis with ATLAS.ti; Sage Publications: Los Angeles, CA, USA, 2014.

79. Fisk, P. People, Planet, Profit: How to Embrace Sustainability for Innovation and Business Growth; Kogan Page: London, UK, 2010.

80. Hart, S.L.; Milstein, M.B. Global sustainability and the creative destruction of industries. Sloan Manag. Rev. 1999, 41, 23.

81. Pretty, J.N.; Morison, J.I.; Hine, R.E. Reducing food poverty by increasing agricultural sustainability in developing countries. Agric. Ecosyst. Environ. 2003, 95, 217-234.

82. Hopwood, A.G.; Unerman, J.; Fries, J. Accounting for Sustainability: Practical Insights; Earthscan: London, UK, 2010.

83. Collins, J.C.; Porras, J.I. Building your company's vision. Harv. Bus. Rev. 1996. Available online: http:/ / www. simpsonexecutivecoaching.com/pdf/orgmission/building-your-companys-vision-collins-porras.pdf (accessed on 28 October 2017).

84. Debbie, T.M.; Linda, F. The role of strategic philanthropy in marketing strategy. Eur. J. Mark. 2002, 36, 689-705.

85. Mintzberg, H. The design school: Reconsidering the basic premises of strategic management. Strategy Manag. J. 1990, 11, 171-195. [CrossRef]

86. Osterwalder, A. The Business Model Ontology: A Proposition in a Design Science Approach. Ph.D. Thesis, University of Lausanne, Lausanne, Switzerland, 2004.

87. Osterwalder, A.; Pigneur, Y.; Tucci, C.L. Clarifying business models: Origins, present and future of the concept. Commun. Assoc. Inf. Sci. 2005, 16, 1-25.

88. Osterwalder, A.; Pigneur, Y. Business Model Generation: A Handbook for Visionaries, Game Changers, and Challengers, 1st ed.; Wiley Sons, Inc.: Hoboken, NJ, USA, 2010.

89. Al-Tuwaijri, S.A.; Christensen, T.; Hughes, K.E. The relations among environmental disclosure, environmental performance, and economic performance: A simultaneous approach. Acc. Organ. Soc. 2004, 29, 447-471. [CrossRef]

90. Jose, A.; Lee, S.M. Environmental reporting of global corporations: A content analysis based on website disclosures. J. Bus. Ethics 2007, 72, 307-321. [CrossRef] 
91. Gao, S.S.; Haravi, S.; Xiao, J.Z. Determinants of corporate social and environmental reporting in Hong Kong: A research note. Acc. Forum 2005, 29, 233-242. [CrossRef]

92. Smith, M.; Taffler, R. The chairman's statement: A content analysis of discretionary narrative disclosures. Acc. Audit. Account. J. 2000, 13, 624-646. [CrossRef]

93. Solomon, A. Could corporate environmental reporting shadow financial reporting? Acc. Forum 2000, 24, 30-55. [CrossRef]

94. Patten, D.M. The relation between environmental performance and environmental disclosure: A research note. Acc. Organ. Soc. 2002, 27, 763-773. [CrossRef]

95. Hahn, R.; Lülfs, R. Legitimizing Negative Aspects in GRI-Oriented Sustainability Reporting: A Qualitative Analysis of Corporate Disclosure Strategies. J. Bus. Ethics 2014, 123, 401-420. [CrossRef]

96. Reimsbach, D.; Hahn, R. The Effects of Negative Incidents in Sustainability Reporting on Investors' Judgments-An Experimental Study of Third-Party Versus Self-Disclosure in the Realm of Sustainable Development. Bus. Strategy Environ. 2015, 24, 217-235. [CrossRef]

97. Patten, D.M. Exposure, legitimacy, and social disclosure. J. Acc. Public Policy 1991, 10, 297-308. [CrossRef]

98. Bernard, H.R.; Ryan, G.W. Analyzing Qualitative Data; Sage Publications: Thousand Oaks, CA, USA, 2010.

99. Jones, C. Exploring new ways of assessing the effect of regulation on environmental management. J. Clean. Prod. 2010, 18, 1229-1250. [CrossRef]

100. Dhaliwal, D.S.; Li, O.Z.; Tsang, A.; Yang, Y.G. Voluntary Nonfinancial Disclosure and the Cost of Equity Capital: The Initiation of Corporate Social Responsibility Reporting. Acc. Rev. 2011, 86, 59-100. [CrossRef]

(C) 2017 by the authors. Licensee MDPI, Basel, Switzerland. This article is an open access article distributed under the terms and conditions of the Creative Commons Attribution (CC BY) license (http:/ / creativecommons.org/licenses/by/4.0/). 